\title{
BORABOY GÖLÜ (AMASYA) VE ÇEVRESINIIN, REKREASYON AMAÇLI KULLANIMDAN KAYNAKLANAN BAŞLICA SORUNLARI
}

Boraboy Lake (Amasya) and Around's Major Problems Based From Recreational Use

Dr. Öğr. Üyesi Eren ŞENOL*

$\ddot{O} z$

Kentleşme, gelir artışı ve ulaşımdaki gelişmeler doğal güzelliklere sahip kirsal alanların rekreasyon amaçlı kullanımını yaygınlaştırmıştır. Bu süreçte yaygın olarak tercih edilen yerlerden biri de göl çevreleridir. Orta Karadeniz Bölümü'nde çok sayıda doğal göl bulunmaktadır. Amasya ili, Taş̧ova ilçesi, Boraboy köyü sinırlart içerisinde yer alan tabiat parkı statüsündeki Boraboy gölü, yöre halk tarafindan bu amaçla yoğun olarak kullanilan yerlerden biridir. Eldeki çalışmada, kullanımdan kaynaklanan problemler vurgulanmış, sorunları gidermek için alınabilecek tedbirler sıralanmıştır.

Anahtar Kelimeler: Rekreasyon, Turizm, Çevre Sorunları, Boraboy Gölü, Amasya.

\section{Abstract}

Urbanization, increase in gain and developments in transportation popularized there recreational use of regions that have natural beauties. Among the prefered regions in this process are lakes. In central blacksea region there are many natural lakes. Boraboy Lake, which is located in Tassova, Amasya, is one of these lakes and has natural park status. This lake is one of the places often used by localpeople for recreational activities. In the study, deficiencies and environment problems arising out of intensive use were emphasized and cautions that can be taken to avert the problems were listed.

Keywords: Recreation, Tourism, Environmental problems, Boraboy Lake, Amasya.

\footnotetext{
* Giresun Üniversitesi, Fen - Edebiyat Fakültesi, Coğrafya Bölümü, eren.senol@giresun.edu.tr
}

Dergiye Geliş Tarihi: 04.04 .2018 


\section{Giriş}

Kentlerde yaşayan insanlar, kırsaldakilere göre daha kaliteli hizmet almaktadırlar. Bedelini, kişiye göre etki derecesi değişmekle birlikte doğal yaşamdan uzak kalarak ödemektedirler. Bu durumdaki kentlilerden bazıları, ruhsal ve psikolojik açıdan rahatlamak adına yeme-içme, uyuma ve çalışma süresi dışındaki serbest zamanlarında, bireysel ya da grup (aile, arkadaş veya aynı amaç için bir araya gelmiş birbirini tanımayan insanlardan oluşan tur kafilesi vb.) halinde kırsal alanlara gitmeyi tercih etmektedirler. Teknolojik yeniliklerin insan yaşantısını kolaylaştırarak serbest zaman artışına neden olması, gelir seviyesinin yükselmesi ile ulaşımdaki gelişmelerin hareket kabiliyetini artırması ve erişebilecek mesafeyi genişletmesi, doğal güzelliklere sahip kırsal alanların, geçmişe oranla daha yaygın olarak ekonomik açıdan değer arz eden lokasyonlara dönüşmesini sağlamıştır.

Türkiye özelinde rekreasyonel faaliyetler için kırsal alanlar içerisinde doğal ve kültürel açıdan önem arz eden köylerin, yaylaların, adak alanlarının, ormanlık sahaların, kaplıca, dere, akarsu ve göl çevrelerinin yoğun olarak tercih edildiği gözlenmektedir. Orta Karadeniz Bölümü’nde çok sayıda doğal göl bulunmaktadır (Lahn 1948, İnandık 1965, Tuncel 1975, Saraçoğlu 1990, Akkan vd. 1993, Hoşgören 1994, Zeybek vd. 2012). Amasya ilinin Taşova ilçesinin Boraboy köyü sınırları içerisinde yer alan Boraboy gölü de bunlardan biridir (Şekil 1).

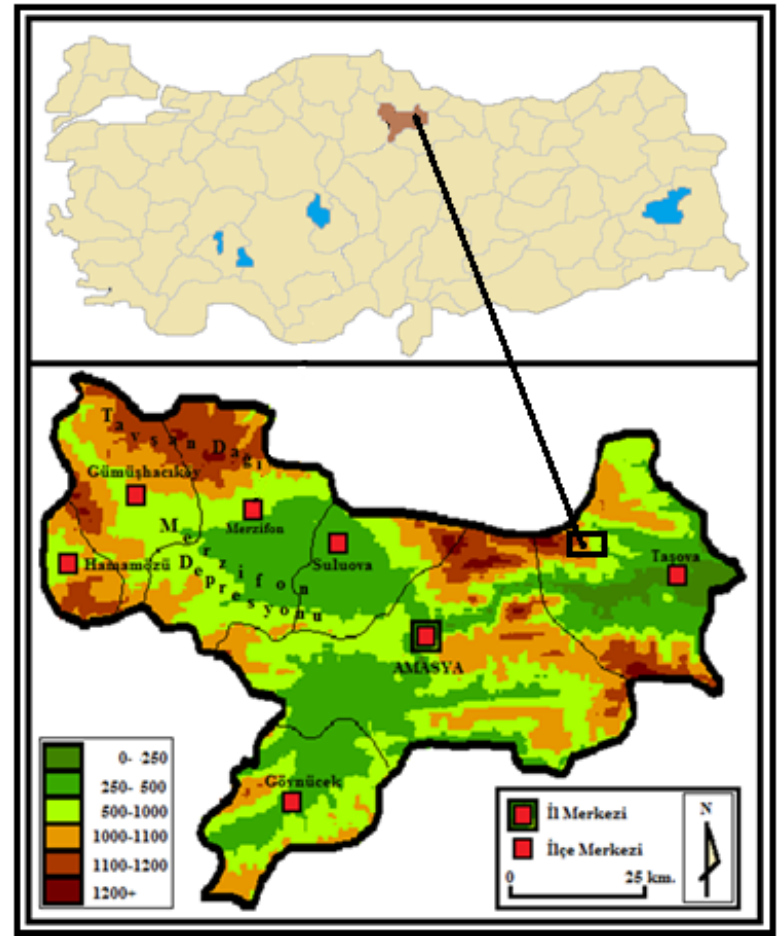

Şekil 1. Boraboy gölü ve çevresinin lokasyon haritast.

Boraboy gölünün adı, oluşum şekli, büyüklüğü ve çevresindeki bitki örtüsü ile ilgili olarak hem internet, hem ansiklopedik, hem de akademik kaynaklarda bilgi kirliliği söz konusudur.

Göle adını veren yerleşmenin Boraboy olan adı 1961'de Gölbeyli; 1995'te ise Bakanlar Kurulu kararı ile tekrar Boraboy olarak değiştirilmiştir. Göl, literatürde Borabay gölü olarak bilinmekte, Karayolları Genel Müdürlüğü tarafından sunulan bazı haritalarda Kocagöl, Google Earth'de Kocabey gölü olarak gösterilmektedir. Adını yerleşmeden aldığına, yerleşmenin adı da yukarıda ifade edildiği üzere Boraboy olduğuna göre, göl adının yöre sakinleri tarafından telaffuz edildiği şekli ile "Boraboy gölü” olarak ifade edilmesi daha doğru olacaktır. 


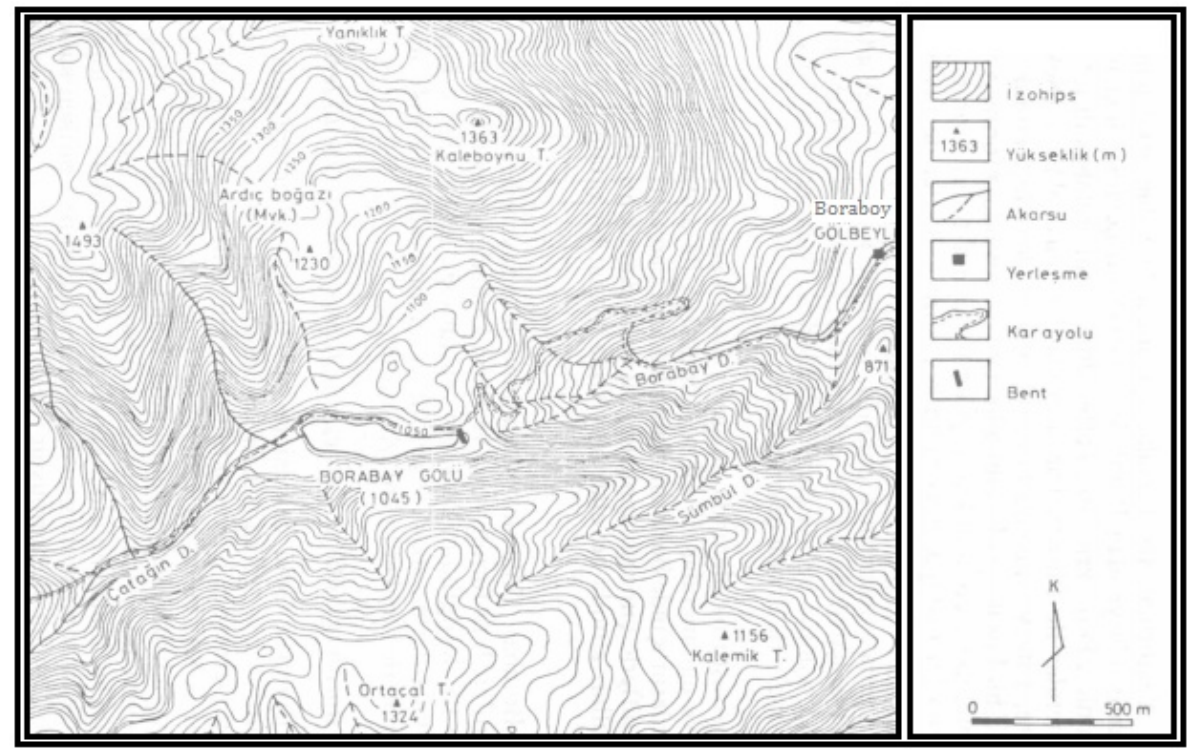

Şekil 2. Boraboy gölü ve çevresinin topografya haritası (Doğu vd., 1994 s.245).

1990 öncesi turizm broşürlerinde ve o dönemlerde basılan bazı ansiklopedik kaynaklarda (Örnek: Türkiye Ansiklopedisi, 1983:117, Rehber Ansiklopedisi, 1984: 215) Boraboy gölünün oluşum bakımından krater gölü olduğu belirtilmiştir. Sonraki dönemlerde gölün, Kaleboynu tepesi ve çevresindeki kütlenin eğim yönünde yer değiştirerek Çatağın deresi yatağını tıkaması sonucunda oluştuğu (Şekil 3, Foto 1) ve bu nedenle oluşum bakımından heyelan set gölü olduğu, çok sayıda bilimsel yayında ifade edilmiştir (Tuncel vd., 1989: 51, Saraçoğlu, 1990: 409, Doğu vd., 1994: 246, Şenol, 1999: 21, Doğanay vd., 2013: 344, Zengin vd., 2014: 9, Avşar vd. 2015: 2). Ne yazık ki hala bazı turizm broşürlerinde, internet kaynaklarında, yöreyi tanıtan TV programlarında ve akademik yayınlarda (örnek: Cansaran vd., 2010: 66) aynı yanlışın tekrarlandığı görülmektedir.

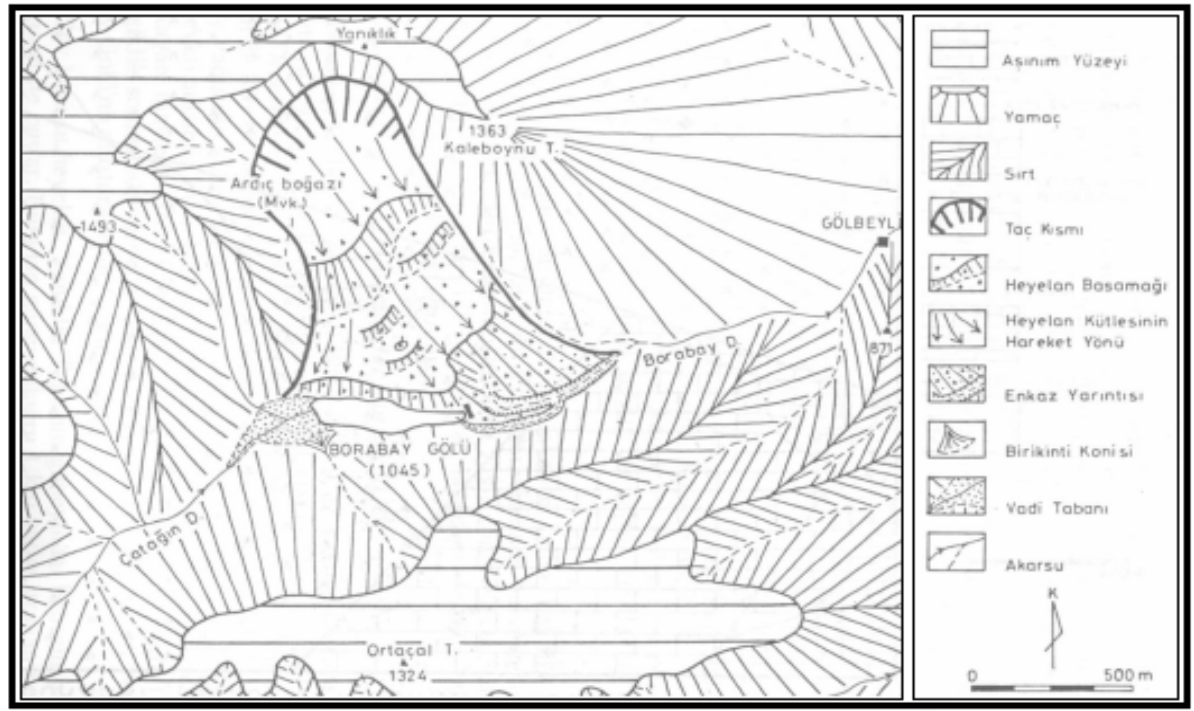

Şekil 3. Boraboy gölü ve çevresinin jeomorfoloji haritası (Doğu vd., 1994:248). 


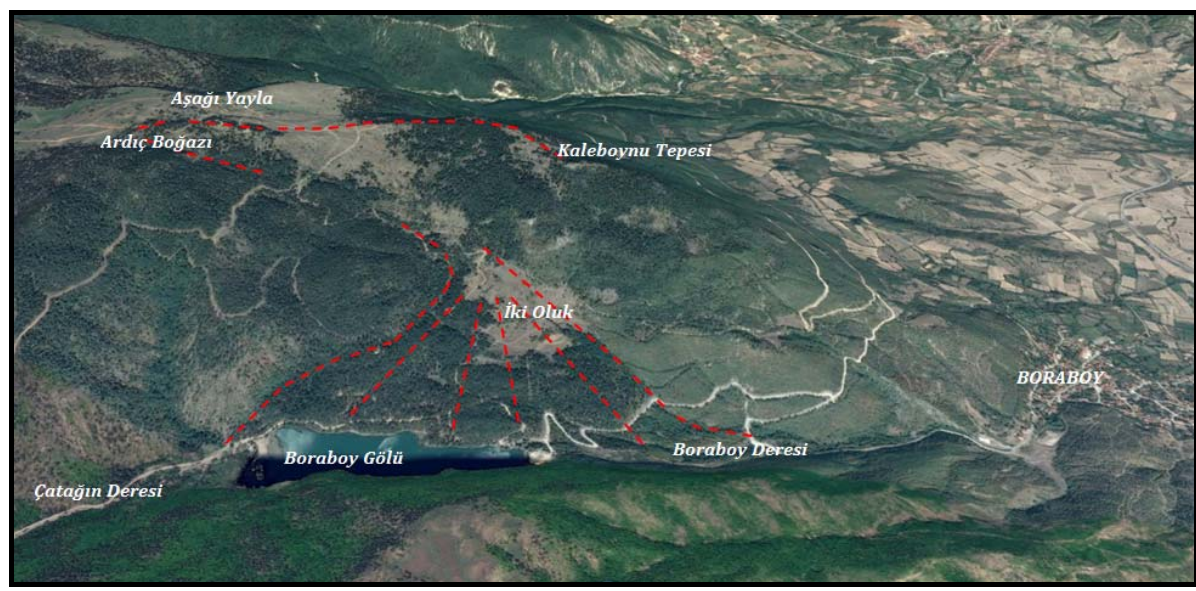

Fotoğraf 1. Boraboy gölü ve çevresinin uydu görüntüsü (Google Earth, 28.03.2018).

Göl, genel olarak $750 \mathrm{~m}$ uzunluğunda ve doğu yarısında 100, batı yarısında ise $200 \mathrm{~m}$ genişliğindedir. 2 km'lik çevre uzunluğuna ve 11 ha.lik $\left(0,11 \mathrm{~km}^{2}\right)$ alana sahiptir. Ancak bir çok kaynakta göl alanı, oldukça abartılı bir şekilde, 2-3 km² olarak belirtilmektedir (Saraçoğlu, 1990: 409, Doğu vd., 249, Doğanay vd., 2013: 344, Atalay vd., 2011: 47). Göl çanağının oluşumunda yukarıda ifade edildiği üzere heyelan etkilidir. Günümüzdeki büyüklüğe ve görünüme ulaşmasında ise gölün doğu kısmına yapılan set, başka bir ifade ile antropojen faktörler de belirleyici olmuştur. Tarım alanlarının sulama suyu ihtiyacını karşılamak için, göl çanağında daha fazla su depolanmasını sağlamak amacı ile yapılan, yaklaşık olarak 5 metre yüksekliğindeki bu set nedeni ile özellikle ilkbahar döneminde göl, batısındaki delta alanını da su altında bırakacak şekilde büyümektedir. Yüzey alanı bir - iki hektar genişlemektedir.

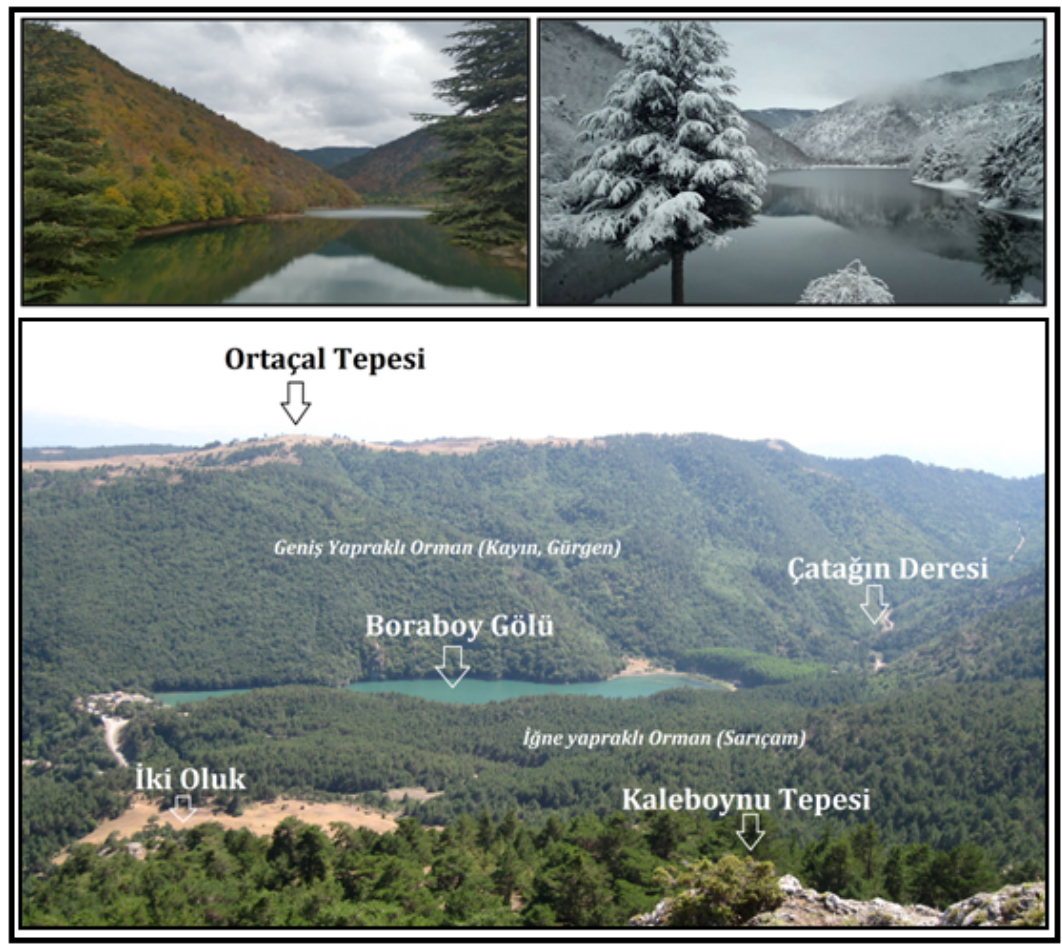

Fotoğraf 2. Boraboy gölünden manzaralar. 
Fazla suları Boraboy deresi aracılığı ile akaçlanan gölün suyu tatlıdır. Su seviyesi kar erimelerine ve ilkbahar yağışlarına bağlı olarak, mayıs sonu haziran başlarında maksimum seviyesine ulaşmaktadır. Yaz yağışlarının azlığı ve suyunun tarımda kullanılması nedeni ile bu dönemden itibaren kış aylarına kadar su seviyesinde düşüş görülmektedir. Ayrıca çoğu zaman ocak-şubat aylarında yüzeyi buz örtüsü ile kaplanmaktadır.

Atalay ve Mortan tarafindan gölün güneye bakan yamaçlarının gürgen kayın gibi ağaçlarla, güney yamaçlarının ise sarıçamlarla kaplı olduğu ifade edilmiş̧tir (Atalay vd., 2011:47). Oysa doğu batı yönünde uzanan gölün kuzey yamaçlarında hakim türün sarıçam olduğu iğne yapraklı ormanlar; güney yamaçlarında ise hakim türün kayın ve gürgen olduğu geniş yapraklı ormanlar görülmektedir. Sahanın bir diğer asli türü gölün batısındaki delta üzerinde yayılış gösteren, ancak 1994'te kesilen söğüt ağaçları idi. Aynı yere kavak ağaçları dikilmiş, onlar da 2011 yılında benzer akıbete uğramıştır.

Bilindiği üzere göllerden içme, kullanma ve sulama suyu temin edilmekte, balık, tuz-soda, elektrik üretilmektedir. Balık ve su kuşları avcılığı ile saz kesimi yapılmaktadır. Ulaşım sağlanmaktadır. Doğaner'in de ifade ettiği gibi göller piknik, kamping, avcılık, yürüyüş yapma, bisiklete binme, fotoğraf çekme ve manzara seyretme gibi çevresel aktiviteler için uygun ortamlardır (Doğaner, 2001: 81). Bu ve benzeri nedenlerle rekreasyon alanı olarak değerlendirilmektedir. Boraboy gölünden, genel olarak tarım alanlarını sulama ve rekreasyon amacı ile yararlanma söz konusudur. Bitki örtüsünün de etkisi ile dört mevsim seyre değer manzarası bulunan; $1045 \mathrm{~m}$. yüksekte yer alması nedeni ile, çevresindeki düşük rakımlı yerleşmelerde (Amasya 400 - $450 \mathrm{~m}$, Taşova 250-300 m, Erbaa 250-300 m, Tokat 350-450 m, Samsun 0-100 m) yaşayan ve yaz sıcağından bunalanlara nispeten daha serin hava koşulları sunan göl ve çevresi, Karadeniz Bölgesi ve Amasya ilindeki önemli turistik çekiciliklerden biridir (Tuncel vd., 1989: 66, Köksal, 1994:20, Evliyaoğlu, 1996:182, Doğanay vd., 2013:344, Elmac1, 2010: 132, Çoban vd., 2015:608).

\section{Amaç ve Yöntem}

Boraboy gölü ve çevresinde turizm amaçlı ilk tesisler 1970'li yıllarda yapılmıştır. Bekçi kulübesi, kır lokantası ve konaklama ihtiyacını karşılamak adına yapılan dokuz adet bungalov tipi kır evine; saha birinci derece doğal sit düzeyinde koruma alanı haline getirildiği için uzunca bir süre yenileri eklenememiştir. Ancak ulaşım sektöründeki gelişmeler nedeni ile Boraboy gölü ve çevresine gelen ziyaretçi sayısının her geçen gün artması, kırsal turizmin popüler hale gelmesi, Amasya ilini turizmde marka haline getirme çabaları, yüksek turizm potansiyeline sahip Boraboy gölü çevresinde yeni düzenlemeler yapılmasını zorunlu hale getirmiştir. Önceleri birinci derece doğal sit alanı olan saha, 1992'de turizm merkezine; 1996'da da TC. Kültür Bakanlığı Ankara Kültür ve Tabiat Varlıklarını Koruma Kurulu'nun 26.05.1996 tarih ve 96/4614 sayılı kararıla da üçüncü derece doğal sit alanı-na dönüştürülmüştür. 03.09.2013 tarihinde tabiat parkl statüsünde korunan alan haline getirilmiştir. $\mathrm{Bu}$ tarihten itibaren sahada mevcut tesisler iyileştirilmiş, ahşap malzeme ile kaplanarak doğa ile uyumlu görünüme kavuşturulmaya çalışılmıştır. Havai elektrik hatları yer altına alınmış, kamera ile gözetleme sistemi kurulmuş, kanalizasyon ve atık su şebekesi oluşturulmuş, gezi yolları-patikalar güvenlik tedbirlerini de kapsayacak şekilde yeniden düzenlenmiştir. Ayrıca mevcut kır evlerine, öncekilere göre daha konforlu olan on kır evi eklenmiştir.

Yazıcı ve Cin 1995'de Uzungöl'ü 60.000 kişinin ziyaret ettiğini belirtmişlerdir (Yazıcı vd., 1997:71). Boraboy gölüne aşağıdaki paragraflarda vurgulanacağı üzere 2017 yılında 70.000'den fazla ziyaretçi gelmiştir. Gelecek 25 yıl içinde Uzungöl'e benzer ilgi görebilecek bu sahanın, başta yapılaşma olmak üzere, orada yaşanan sorunları yaşamaması adına mevcut kullanım özelliklerinin tespiti büyük önem taşımaktadır. Bu bağlamda eldeki çalışmada göl ve çevresinde rekreasyonel faaliyetlere bağlı olarak ortaya çıkan çevre sorunlarını tespit etmek amaçlanmıştır. Halihazırdaki yararlanma şeklinin sürdürülebilirliği irdelenmiş, öneriler sunulmuştur. Amaca ulaşmak için, baba ocağım olan araştırma sahasına sık sık gidilerek, gözlemde bulunulmuş, yöre sakinleri, ziyaretçiler, işletmeciler ve idari anlamda sorumluluk sahipleri ile görüşmeler yapılmıştır. Gözlem ve görüşmelerden elde edilen sonuçlar nitel olarak değerlendirilerek metin oluşturulmuş̧ur. 


\section{Bulgular}

\section{1. Boraboy Gölü ve Çevresine Gelen Ziyaretçiler Hakkında Genel Bilgiler}

Boraboy gölü yıllardan beri yaz döneminde, özellikle hafta sonlarında yoğun ziyaretçi akınına uğramaktadır. Durum böyle olmakla birlikte, gelen ziyaretçi sayısı hakkında nitelikli veri toplama yoluna ne yazık ki gidilmemiştir.

Şenol, Boraboy'da Arazi Kullanımı adlı yüksek lisans tezinde Turizm Alanları başlığı altında Boraboy gölüne gelen ziyaretçilerle ilgili olarak Amasya İl Turizm Müdürlüğü’nden temin ettiği 1993 1997 arası verilere yer vermiştir. 1993 ve 1994 yıllarında günübirlikçiler, 1995-1997 yılları arasında ise sadece konaklayanlar dikkate alınarak derlenen ve ilgililere sunulan verilerin, ilgili kurumun isteği üzerine o dönemlerde göl çevresindeki tesislerin işletme hakkına sahip belediyenin ilgili yetkilileri tarafından il müdürlüğüne iletilen veriler olduğunu belirtmiștir. Bu verilere göre Boraboy gölüne 1993'te 12970, 1994'te 16439 günübirlikçi gelmiş; çevresinde 1995'te 2663, 1996'da 909, 1997'de ise 893 gece konaklama gerçekleşmiştir (Şenol, 1999:70).

Günümüzde tabiat parkı girişinde ziyaretçilerden bilet karşılığında araç türüne dikkat edilerek giriş ücreti alınmakta, araç türü belli bir katsayı ile çarpılarak gelen ziyaretçi sayısı yaklaşık olarak tespit edilmekte, ilgili kurumlara sunulmaktadır. Civar köylerden gelenlerden veya tanıdıklardan vb. ücret alınmaması, araçlardaki ziyaretçi sayısını tespit etmek yerine belli bir katsayı kullanılması ve yabancı turistlerle ilgili kayıtlara yer verilmemesi nedeni ile verilerin yine gerçekçi ve yeterli olduğunu söylemek güçtür. Ancak genel durumu göstermesi, asgari ziyaretçi sayısı hakkında fikir vermesi açısından büyük önem taşıdığını da ifade etmek gerekir. Yukarıda anlatılan yöntem dâhilinde sunulan verilere göre Boraboy gölü ve çevresine, 2017 yılı içinde, genellikle otomobil ile özellikle yaz döneminde 73806 ziyaretçi gelmiş, 1041 gecelik konaklama olmuştur (Tablo 1).

Tablo 1. Aylara Göre Boraboy Gölü Tabiat Parkına Giriş Yapan Araçlar ve Ziyaretçiler ile Konaklama Sayllarl (2017).

\begin{tabular}{|l|c|c|c|c|c|c|c|c|c|c|c|c|c|}
\hline & $\mathbf{O}$ & $\mathbf{S}$ & $\mathbf{M}$ & $\mathbf{N}$ & $\mathbf{M}$ & $\mathbf{H}$ & $\mathbf{T}$ & $\mathbf{A}$ & $\mathbf{E}$ & $\mathbf{E}$ & $\mathbf{K}$ & $\mathbf{A}$ & Toplam \\
\hline Bisiklet & 0 & 0 & 0 & 0 & 0 & 0 & 0 & 0 & 0 & 0 & 0 & 0 & 0 \\
\hline Motosiklet & 0 & 0 & 2 & 28 & 30 & 42 & 0 & 0 & 0 & 0 & 0 & 0 & 102 \\
\hline $\begin{array}{l}\text { Otomobil } \\
\text { Kamyonet }\end{array}$ & 0 & 0 & 94 & 716 & 1674 & 3821 & 6060 & 4564 & 3621 & 763 & 0 & 0 & 21313 \\
\hline Minibüs & 0 & 0 & 2 & 31 & 107 & 111 & 43 & 27 & 63 & 12 & 0 & 0 & 396 \\
\hline Midibüs & 0 & 0 & 1 & 2 & 25 & 35 & 6 & 7 & 6 & 6 & 0 & 0 & 88 \\
\hline Otobüs & 0 & 0 & 0 & 2 & 0 & 3 & 0 & 1 & 1 & 2 & 0 & 0 & 9 \\
\hline Kişi & 0 & 0 & 341 & 2809 & 7312 & 14828 & 19155 & 14565 & 12050 & 2746 & 0 & 0 & 73806 \\
\hline Konaklama & 0 & 0 & 0 & 0 & 0 & 550 & 176 & 237 & 44 & 37 & 0 & 0 & 1041 \\
\hline
\end{tabular}

Çalışmanın ilerleyen kısımlarında vurgulanacağı üzere yöreye gelenler daha çok piknik yaparak vakitlerini değerlendirmektedirler. Kış döneminde hava koşullarının bu aktiviteye izin vermemesi nedeni ile ziyaretçi sayısı azalmakta, tesisler ekonomik olarak işletilememekte; gelenlerden giriş ücreti talep edilmemektedir. Gözlemlerimize dayanarak kış yarıyılında gelen ziyaretçi sayısının tabloda ifade edildiği gibi "sıfır" olmadığını, ancak bir önceki cümlede ifade edilen durum, tesislerin kış koşullarına uygun olmaması, ulaşım riskleri, nüfus hareketliliğinin azalması gibi faktörlerin etkisi ile oldukça az olduğunu söyleyebiliriz. Yine sahadaki izlenimlerimiz ışı̆̆ında yöreye ziyaretçilerin hafta sonlarında, özellikle pazar günlerinde giriş yaptıklarını; haziran, temmuz ve ağustos aylarının pazar günlerinde giriş yapan araç sayısının 250'nin, ziyaretçi sayısının ise 1000'in üzerinde olduğunu; dini bayramlarda bu sayının katlandığını belirtebiliriz. Boraboy Eğitim, Kültür ve Dayanışma Derneği öncülüğünde göl çevresinde düzenlenen "Boraboy Gölü Şenliği”'-nde ziyaretçi sayısının gün içinde 5000'e yaklaştığını ifade edebiliriz. 
Göl ve çevresindeki tesisler önceleri Boraboy Belediyesi tarafından işletilmekte idi. 06.12.2012 tarih ve 6360 sayılı yasa gereği nüfus miktarı 2000'in altına düştüğü için 2014 yılında belediye lağvedilmiştir. Orman ve Su İşleri Bakanlığı, XI. Bölge Müdürlüğü tarafından düzenlenen ihale ile işletme hakkı, yöreden İstanbul'a göç edenler tarafından kurulan Boraboy Eğitim, Kültür ve Dayanışma Derneği bünyesinde oluşturulan iktisadi işletme tarafından alınmıştır. İşletme sözleşmesi gereğince 2017 yılında dini bayram günlerinde sahaya gelen ziyaretçilerden "giriş" ücreti alınmamıştır. Şenlik gününde de ziyaretçiler genelde yöre insanı olduğu için giriş ücreti ödememektedirler. Bunlar da kayıt altına alınmış ve verilere eklenmiş olsayd1, yıl içerisindeki toplam ziyaretçi sayısının 100 000'i aştığ istatistiklere de yansırdı.

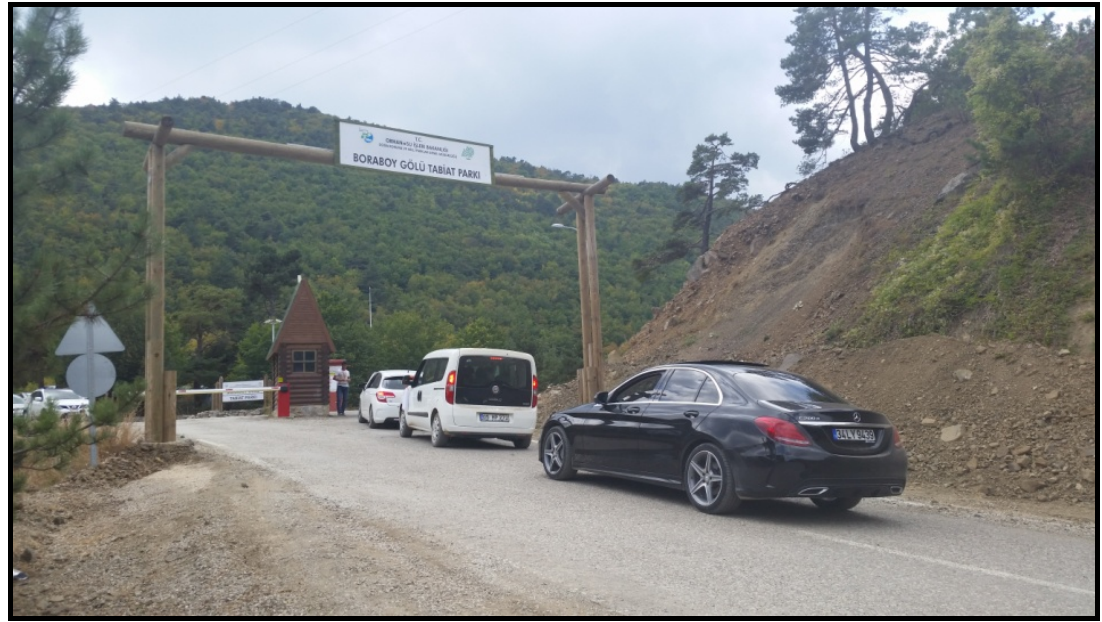

Fotoğraf 3. Boraboy Gölü Tabiat Parkı girişi.

\section{2. Ziyaretçilerin Boraboy Gölü ve Çevresindeki Faaliyetleri}

Boraboy gölü ve çevresinde ziyaretçilerin ihtiyaçlarını karşılamak adına halihazırda bir kır lokantası, on dokuz adet bungalov tarzı kır evi, bir büfe, iki WC, bir mescit, dokuz çeşme, on deniz bisikleti ve göl çevresine gelişigüzel olarak serpiştirilmiş çok sayıda piknik masası bulunmaktadır (Şekil 4, Fotoğraf 4).

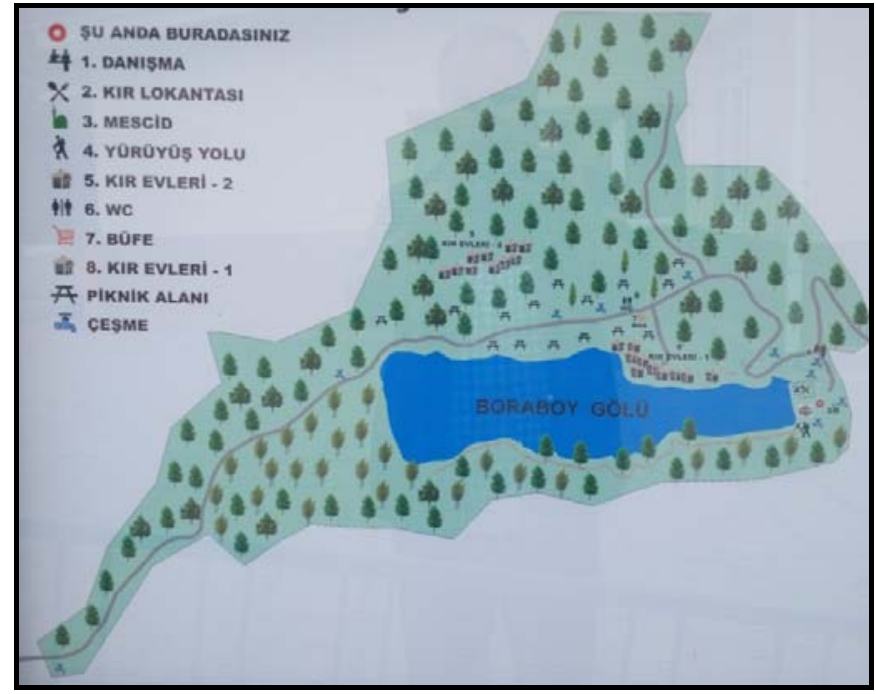

Şekil 4. Boraboy gölü tabiat parkı ve çevresindeki donatıların krokisi (Kaynak:Orman ve Su İşleri Bakanlı̆̆ı, XI. Bölge Müdürlü̈̆̈̈). 


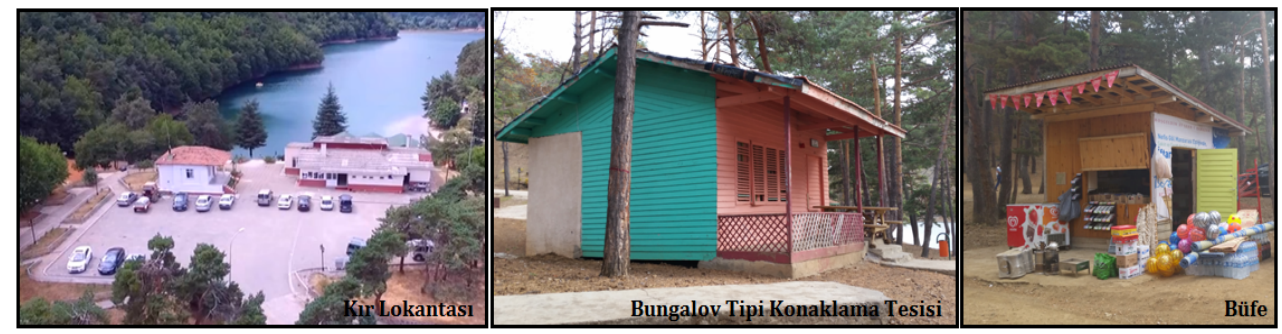

Fotoğraf 4. Göl çevresindeki tesislerden bazılarl: Kır lokantası, kır evi, büfe.

Boraboy gölü ve çevresine gelen ziyaretçiler zamanlarını çevre gezisi yaparak, kayığa-deniz bisikletlerine binerek, hamakta uyuyarak, top-iskambil-tavla-okey oynayarak, balık tutarak, mangal başında yemek hazırlayarak vb. geçirmektedirler (Fotoğraf 5). Yaş ve cinsiyete göre aktiviteler farklılık göstermektedir. Kadınların daha çok sofra-yemek hazırlayarak, erkeklerin mangal başında uğraşarak, çocukların topla oynayarak, çevre gezisi yaparak ve balık tutarak, yaşlıların ise sohbet ederek veya uyuyarak vakitlerini değerlendirdikleri gözlenmektedir.
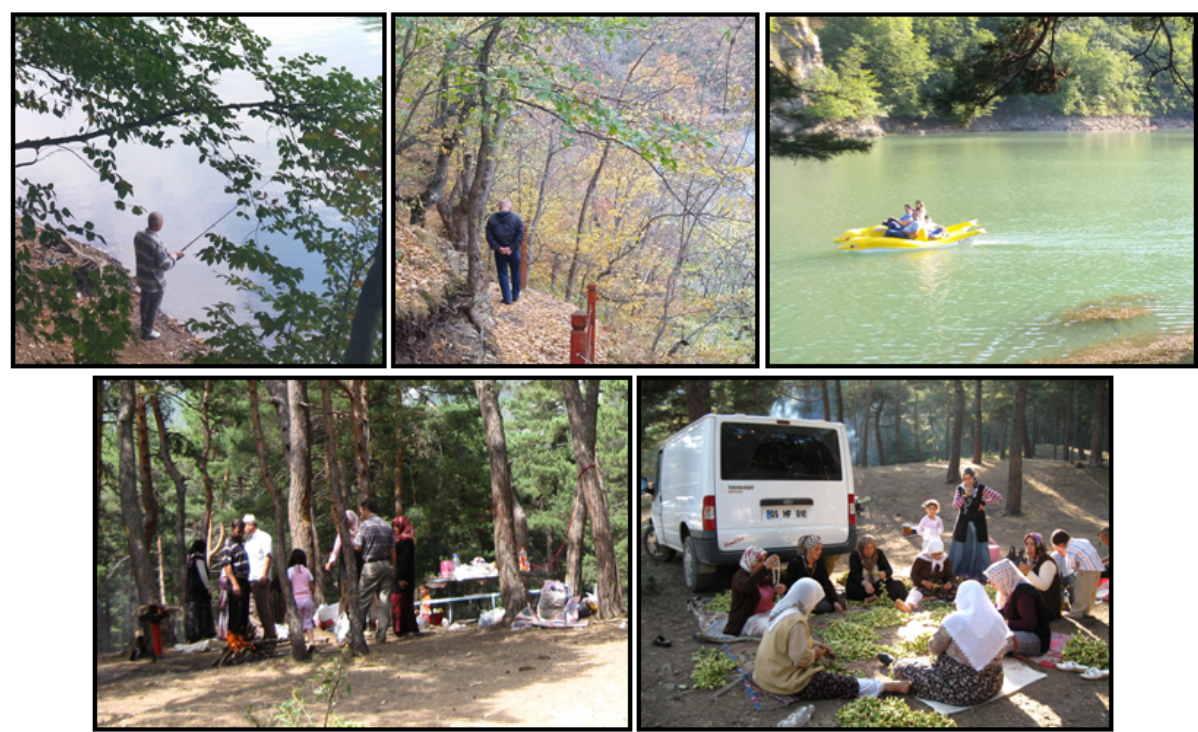

Fotoğraf 5. Ziyaretçilerin göl çevresindeki aktivitelerinden bazıları: Balık tutmak, çevre gezisi yapmak, kayı̆̆a binmek, piknik yapmak ve uç örnek: Bamya dizmek.

Boraboy gölü ve çevresi daha çok günübirlikçiler tarafından kullanılmaktadır. Konaklama hizmeti almayan günübirlikçiler kır lokantasından yararlanmayı da genelde tercih etmemektedirler. Girişte yapılan ödeme, büfeden yapılan küçük alışverişler ve deniz bisikletlerini kullanma ücreti haricinde harcama yapılmaması nedeni ile mevcut kullanımın yöreye ekonomik katkısı azdır.

\section{3. Boraboy Gölü ve Çevresinde, Rekreasyonel Kullanımından Kaynaklanan Çevre Sorunları}

Boraboy gölü ve çevresinin rekreasyonel faaliyetlere sahne olması, göl çevresinin korunmasını sağlamış, köyün tanınırlığına, marka değerine, ulaşım altyapısına olumlu etkide bulunmuştur. Yörede beklentilerin aksine, istihdama (sadece 15 kişi istihdam edilmiş durumda); diğer sektörlerin gelişmesine (ziyaretçiler ihtiyaçlarını geldikleri yerden karşıladıkları için yöre insanı başta tarım ve hayvancılık olmak üzere ürünlerini pazarlayamamakta) ve ödemeler dengesine (ziyaretçiler sahada ödedikleri giriş ücreti hariç fazlaca harcama yapmamaktadırlar) katkısı sınırlı kalmıştır. Ekonomik faydanın arzu edilen düzeyde olmadığı bu sahada, rekreasyonel kullanımdan kaynaklanan bazı sorunlar belirmiştir. En belirgin olanı ise katı atık birikimidir. 


\section{3. 1. Katı Atık Birikimi}

Üretimden tüketime kadar olan tüm aşamalarda ortaya çıkan ve kullanıcının artık işine yaramayan maddelerin tamamı atık olarak tanımlanır (www.tdk.gov.tr). İnsanların çevreye bıraktığı atıklar, ayrıştıııcılar tarafından, atığın özelliğine göre belli bir zaman diliminde dönüştürülür. Doğal süreç böyle olmakla birlikte, nüfusun yoğunlaştığı alanlarda ayrıștıııcıların kapasitesi üzerinde atık bırakılması ve doğada çözünme süresi uzun olan yapay maddelerin sıkça kullanılıp doğaya bırakılması, tüm dünyanın ortak soruna haline gelmiştir. Katı atık sorunu olarak tanımlanan bu durum turizmin geliştiği alanlarda, özellikle hassas ekosistemlere sahip kırsal alanlarda, geri dönüşü güç değişimleri de beraberinde getirmektedir.

Turizm yllın belli dönemlerinde, belli yerlerde yoğunlaşmaktadır (Olalı, 1990: 390). Turizme açılan sahalarda nüfus miktarı yıl içinde değişiklik gösterdiğinden, katı atık toplanması ve bertarafı için yil boyu araç ve personel bulundurulması ekonomik olmamaktadır. Gelecek ziyaretçi sayısı tahminlere dayalı olduğundan turizm sezonunda istihdam edilen personel yetersiz kalabilmekte veya fazla olabilmektedir. Bu nedenle genel olarak özellikle günübirlikçiler tarafından kullanılan alanlarda katı atık sorunu yaşanmaktadır. Nitekim Bekdemir, Elmacı ve Sezer (2010:909) Dilek Yarımadası, Taş (2009: 25) Gaga gölü, Yazıcı ve Cin (1997:73) Uzungöl, Somuncu ve Yiğit (2008: 399) ise Göreme çevresinde günübirlik kullanım nedeni ile ortaya çıkan çöp sorununa vurgu yapmışlardır.

Doğu, Çiçek ve Gürgen, 1994 yllında yayınlanan Borabay Gölü isimli eserlerinde çoğunlukla günübirlik kullanıma hizmet eden sahada çevre temizliğine önem verilmediğini, belirgin bir çevre kirliliği olduğunu dile getirmişler, soruna dikkat çekmişlerdir (Doğu vd., 1994: 253). Aradan geçen çeyrek yüzyıla yakın sürede sorunun çözümüne dair adımlar atıldığı, olumlu gelişmeler olduğu söylenebilir. Ancak ziyaretçilerin altyapı yetersizliğinden sonra en çok dile getirdikleri sorunun bu olması, gelişmelerin yeterli olmadığını göstermesi bakımından önem taşımaktadır.

Boraboy gölü ve çevresi, yılın her döneminde farklı manzaralar sunarak çekiciliğini korumakta ise de değişik gerekçelerle daha çok yaz döneminde ve bu dönem içinde de özellikle hafta sonlarında ziyaretçi akınına uğramaktadır. Bu günlerde bırakılan atıklar piknik yapılan sahanın geniş olması, piknik yapılacak alanlarda sınırlama olmadığından ziyaretçilerin bu sahanın herhangi bir noktasında gelişigüzel yer seçmesi, bunlara karşılık personel sayısının yetersiz olması nedeni ile zamanında toplanamamakta; katı atık birikimi baskın bir sorun olarak dikkat çekmektedir. Özellikle cumartesi günlerinde, ziyaretçilerin akşam saatlerinde sahayı terk ederken bıraktıkları atıklar, hava karardığı için ilgili görevliler tarafından toplanamamakta, bir sonraki günün ziyaretçileri hiç arzu edilmeyen kirli ortamla karşı karşıya kalmaktadırlar. Dini bayram tatillerinde de benzer durum görülmektedir. Tatil boyunca her gün çok sayıda ziyaretçi gelmekte, bunlar sahayı geç terk etmektedirler. Aynı dönemde tatil nedeni ile çalışan personel sayısında azalma görülmekte, il özel idaresi denetimindeki çöp toplama araçları sahaya daha az uğramakta ya da hiç uğramamaktadır. Ziyaretçi yoğunluğunun fazla olduğu günlerde gözlenen bu aksaklık, genel bir durummuş gibi algılanmakta, göl ve çevresinin marka değerini olumsuz etkilemektedir.

Ziyaretçilerin büyük çoğunluğu atıklarını çöp bidonlarına attıklarını ifade etmektedirler. Ancak sözler ile davranışlar arasında paralellik olmadığı, sahada gelişigüzel bırakılmış atıklardan anlaşılmaktadır. Ayrıca katı atıklar çöp konteynırlarına bırakılsa bile çöplerin zamanında toplanmaması, konteynırların pazar günleri için yetersiz kalması, konteynır çevresine bırakılan çöplerin hayvanlar tarafından dağıtılması nedeni ile hoş olmayan görüntüler ortaya çıkabilmektedir (Fotoğraf 6).

Katı atıklar görüntü kirliliğine, kokuya, hastalık yayabilecek sinek-fare üremesine vb. yol açtığı için, çöplerden yayılan tozlar, sular ve gazlar çevreyi tehlikeli bir biçimde kirlettiği için (Sargın, 2003:162) bunların zamanında toplanması ve bertarafı da önem taşımaktadır. Göl çevresinde toplanan katı atıklar önceden ziyaretçilerin rahatsız olmayacağı, gölün $1 \mathrm{~km}$ kuzey doğusundaki alana, İki oluk mevkii girişine bırakılmakta idi. Sorun çözümlenmemekte, sadece yer değiştirmekteydi. Günümüzde konteynırlarda toplanan katı atıklar Amasya Katı Atık Birliği uhdesinde, Amasya'daki tesislerde geri dönüşüme kazandırılmakta ve bertaraf edilmektedir. 

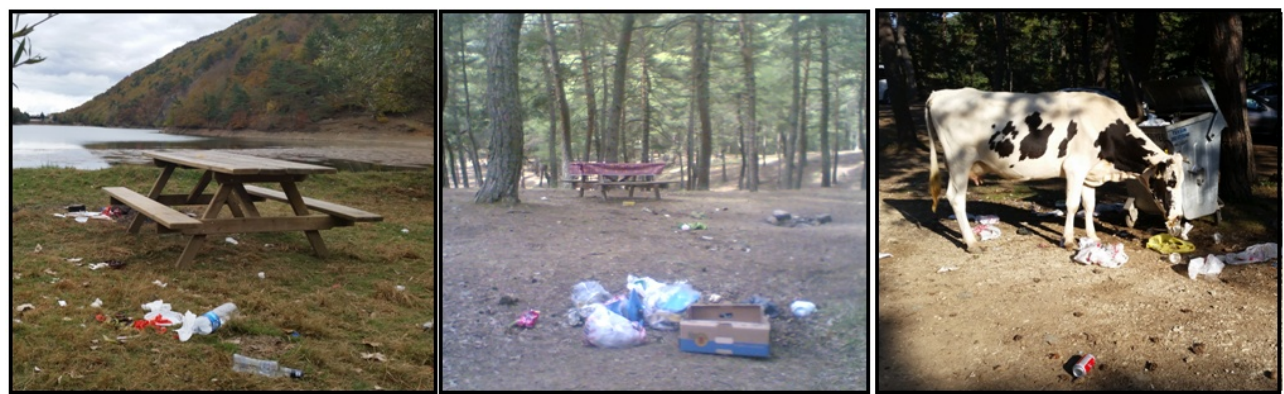

Fotoğraf 6. Piknik sonrası toplanmayan atıklar, toplanıp bir yere ya da konteynirlara birakllan atıklar. Bunların hayvanlar tarafindan dağıtılması, katı atık sorununu belirgin hale getirmektedir.

\subsection{Biyoçeşitliliğe Müdahale}

Boraboy gölü ve çevresi zengin bitki örtüne sahiptir. Güney yamaç yüksek eğim nedeni ile ziyaretçiler tarafından piknik yapmak amacı ile kullanılmamaktadır. Burada sadece göl çevresinde doyumsuz manzaralar eşliğinde yürüyüş yapmayı sağlayan güvenlik tedbirleri alınmış dar bir patika bulunmaktadır. Dolayısı ile bu kısmın genel olarak korunduğunu söyleyebiliriz. Eğimin daha az olduğu kuzey yamaç piknik alanı olarak değerlendirilmektedir. Burada bitki örtüsüne yer yer zarar verildiği görülmekte ise de bu durum ciddi boyutlara varacak düzeyde değildir. Ancak aynı ifadeleri, orman altı florasını oluşturan başta eğrelti otları olmak üzere otsu türler için söylemek mümkün değildir. Hal böyle olmakla birlikte göl çevresinde biyoçeşitliliğe asıl müdahale batı kıyılarda olmuştur. Göle su taşıyan Çatağın deresinin oluşturduğu küçük deltadaki söğüt ağaçları 1994'te kesilmiş, yerine kavak ağaçları dikilmiştir. Bunlarda 2011'de kesilmiştir. Somuncu, Kurum, Çabuk Kaya, Özelçi Eceral ve Akpınar'ın da ifade ettiği gibi bitki örtüsü, gerek toprağın gerekse suyun muhafaza edilmesini sağlayan özelliğe sahiptir (Somuncu vd., 2012:93). Yörede söğ̈̈t ve kavak ağaçları kesilerek sadece su ve toprağın muhafazasında zafiyete düşülmemiş; aynı zamanda kurbağa ve balıklara yumurtlama döneminde yuva olan bu alanların tahribi ile faunaya da zarar verilmiştir.

Gölde sazan ve yayın türü balıklar yaşamaktadır. A $\breve{g}$ ile avcılı̆̆ın yapılmadığı sahada ziyaretçilerin, sportif olta balıkçılığı yapmasına izin verilmektedir. Bu yönü ile sahanın, sürdürülebilir olarak kullanıldığını söyleyebiliriz. Ancak son on yıl içinde gölde tatlı su sstakozlarına rastlanmaktadır. Resmi olarak aşılama yapılmamış iken, asli tür olmayan bu canlıların türemiş ve çoğalmış olması, dikkatle incelenmesi gereken, mevcut faunaya ve dolayısı ile ekosisteme zarar vermesi muhtemel olan bir gelişmedir.

Sahada ziyaretçiler tarafindan kozalaklar toplanarak, çiçekli otsu bitkiler kökünden sökülerek, ağaç türleri kesici aletlerle yaralanarak bitki örtüsüne zarar verilmektedir (Fotoğraf 7). Ancak kanaatimce asıl büyük tehlike sahada semaver, mangal veya isınmak için pervasızca ateş yakılıyor olmasıdır. Reçineli ağaçların bulunduğu bu alanda bir anlık dikkatsizlik sonucunda yangın çıkabileceği, telafisi güç zararların oluşabileceği aşikâr iken, konu ile ilgili düzenleme veya denetleme yapılmıyor olması ilginç bir durumdur.
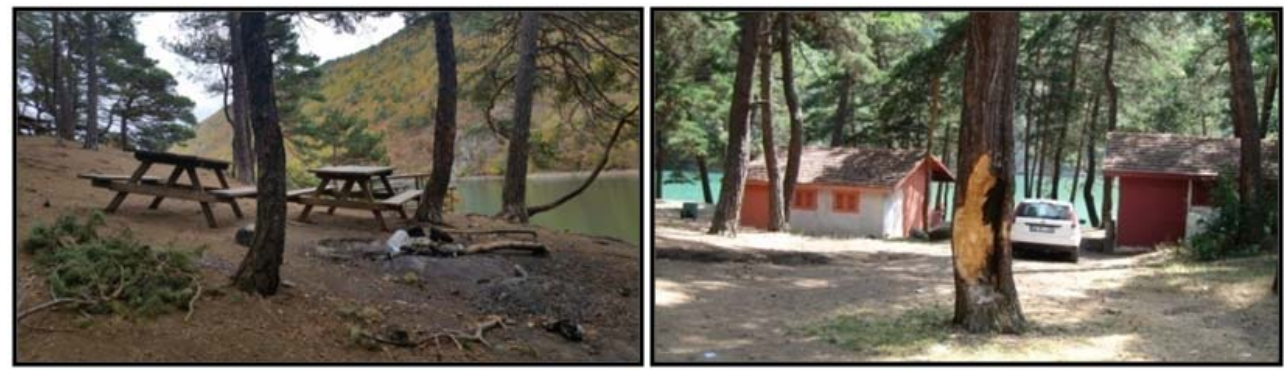

Fotoğraf 7. Ziyaretçiler tarafindan kesilmiş dallar, gövdesi yaralanmış ağaçlar. 


\section{3. 3. Erozyon}

Toprağın üst kısmının zaman içinde ve yavaş bir şekilde akarsu, sel suları ve rüzgar başta olmak üzere dış kuvvetler tarafından taşınmasına erozyon denir. Doğal yolla gerçekleşen erozyon, insanın özellikle bitki örtüsüne yaptığı müdahalelerle şiddetlenebilmektedir. Boraboy gölünün piknik yapılan kuzey yamacında orman altı florası yok olmuştur. Ayrıca ziyaretçilerin ihtiyaçlarını karşılamak adına yol açmak sureti ile kısıtlı alanlarda bitki örtüsüne müdahale edilmiş, yamaç dengesi bozulmuştur. Bu yerlerde açığa çıkan toprağın eğim yönünde, göle doğru taşındığı gözlenmektedir (Fotoğraf 8). Ciddi derecede erozyondan bahsetmek mümkün olmamakla birlikte, hassas yapıya sahip yörede gelişim dikkatle izlenmeli; hem toprağı korumak, hem de bunların gölde birikmesini önlemek için tedbirler alınmalıdır.
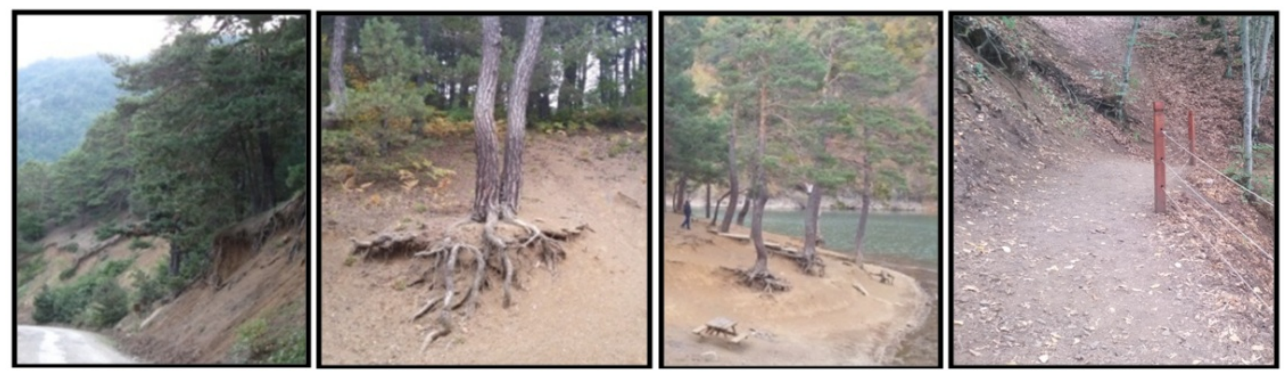

Fotoğraf 8. Göl çevresinde motorlu taşıtlar için açılan yollar ve yayalar için açılan patikalar nedeni ile yamaç dengesinin bozulduğu alanlarda erozyon meydana gelmektedir.

\section{2 .3. 4. Gürültü Kirliliği}

Gürültü, TDK Büyük Sözlük’te “aralarında uyum bulunmayan düzensiz seslerin bütünü, patırt1, şamata (www.tdk.gov.tr.)"; 11 Aralık 1986 tarih ve 19308 sayılı Resmi Gazete'de Yayınlanan Gürültü Kontrol Yönetmeliği'nde "gelişigüzel yapısı olan ses spektrumudur ki sübjektif olarak istenmeyen ses" olarak tanımlanmıştır. Konu ile ilgili eser sunan araştırmacılar da yukarıdaki tanımlara uygun olarak, insanda fizyolojik veya psikolojik olarak rahatsızlık oluşturan sesleri gürültü kirliliği olarak tanımlamışlardır (Güler vd., 1994:12; Yıldız vd., 2005:146, Şahin, 2014:723).

Gürülttü daha çok kentlerde hissedilen çevre sorunudur. Nitekim Sargın (2003:163) Isparta, Deniz (2003:165) Van, Kaya (2005:204) Ağrı, Mor ve Çitçi (2008:207) Elazı̆̆, Aylar ve Çoban (2010:155) Amasya kentlerinin çevre sorunlarını konu alan çalışmalarda ilgili kentlerin önemli sorunlarından birinin de gürültü kirliliği olduğunu ifade etmişlerdir. Güremen'de Amasya kentinde trafik kaynaklı gürültünün ciddi boyutlarda olduğunu tespit etmiştir (Güremen, 2014:40). Ziyaretçilerin kırsal alanlara yönelmesinde daimi ikamet alanlarındaki gürültü kirliliği; gidilecek yerin seçiminde ise sessizlik, sakinlik etkili olabilmektedir. Gidilen yerde oluşan kalabalık grupların birbirinden bağımsız olarak hareket ediyor olması, yüksek sesle müzik dinlenmesi, yüksek sesle konuşmalar, nidalar, motorlu taşıt ve korna sesleri, sesi maskeleyen unsurlar da olmadığ 1 için kırsalda daha net duyulmakta; bu durum göreceli olarak rahatsızlık oluşturmakta, gürültü kirliliğine neden olmaktadır. Kentlerden farklı olarak bu alanlarda oluşan gürültü yöredeki yaban hayatı için de tehdit oluşturmaktadır. Yazıcı ve Cin "Uzungöl Turizm Merkezinde Coğrafi Gözlemler" isimli eserlerinde bu duruma dikkat çekmişler, artan turist ve ziyaretçi sayısına bağlı olarak ortaya çıkan yoğun motorlu taşıt trafiği ve gürültünün yaban hayatı için olumsuz etkileri olduğunu belirtmişlerdir (Yazıcı vd., 1997:74).

Yukarıda sıralanan tavır ve davranışlara ek olarak göl çevresinin jeomorfolojik özellikleri nedeni ile Boraboy gölü çevresinde gürültü kirliliği yaşanmaktadır. Boraboy gölü vadi içerisinde yer almaktadır. Gölün güney yamacı kuzey yamacına oranla oldukça eğimlidir. Ziyaretçiler bu nedenle piknik yapmak için kuzey yamacı kullanmakta, burada üretilen yüksek ses güney yamaçta yankılanarak gürültü etkisini artırabilmektedir.

Söz konusu gürültü kirliliği olduğunda soruna yol açan ses, sesi oluşturanlar tarafindan gürültü olarak algılanmayabilmektedir. Durum böyle olmakla birlikte ziyaretçilerin çevresindekilere karşı 
mümkün olduğunca saygılı olmaları, empati ile yaklaşmaları sorunu çözecektir. Aykırı tutum ve davranışlarda bulunanların maddi cezalara maruz kalması, istenmeyen bir yöntem olmakla birlikte sonunun çözümüne katkı sağlayacaktır.

\section{3. 5. Görüntü Kirliliği}

Fiziki ve beşeri çevrenin doğal çevre ve insan tabiatıyla uyumsuz ve sağlıksız ve rahatsız edici hale getirilmesine görüntü kirliliği denir. Gürültü ve koku kirliliğinde olduğu gibi aynı görüntü, farklı kişiler tarafından olumlu-olumsuz olarak algılanabilir. Emiroğlu'nun da ifade ettiği gibi insanı yoran rahatsızlık veren manzaralar görüntü kirliliği olarak adlandırılır (Emiroğlu, 2009: 387). Olumsuz olarak algılanan görüntü kişide huzursuzluk, yorgunluk bezginlik, dikkat dağılması, isteksizlik, verimsizlik, göz yorgunluğu aşırı sinirlilik, baş dönmesi gibi fiziksel ve psikolojik sağlık sorunlarına sebep olabilir.

Turizme sahne olan alanlarda yapılaşmaya, yol kenarındaki ticarethanelere, unsurların zarar görmesine bağlı olarak görüntü kirliliği oluşmaktadır. Somuncu Göreme'de hediyelik eşya satıcılarının ve naylon seraların oluşturduğu görsel kirliliğe dikkat çekmiştir (Somuncu vd., 2009:399). Benzer durumlar Uzungöl için de dile getirilmiştir (Yazıcı vd., 1997:73). Akpınar ve Akbulut (2007:18) Hafik; Çavuş (2014:48) Sera gölü çevresindeki tesislerin doğal peyzajla uyumlu olmadığını belirtmişlerdir. Hazine arazisi statüsündeki Boraboy gölünün çevresinde rekreasyonel faaliyetler için yapılan tesisler haricinde yap1 yoktur. Tabiat parkı olması nedeni ile de kontrolsüz yapılaşma gibi bir durum da gerçekleşmemiştir. Mevcut haliyle genel olarak doğal güzelliğini korumaktadır. Bununla birlikte gelişigüzel park edilmiş araçlar, çöp yı̆̆ınları, ateş yakılan yerlerde oluşan siyah lekeler, eskimiş bakımsız beton-metal karışımı piknik masaları seyrine doyum olmayan manzarada görüntü kirliliğine neden olmaktadır (Fotoğraf 9).

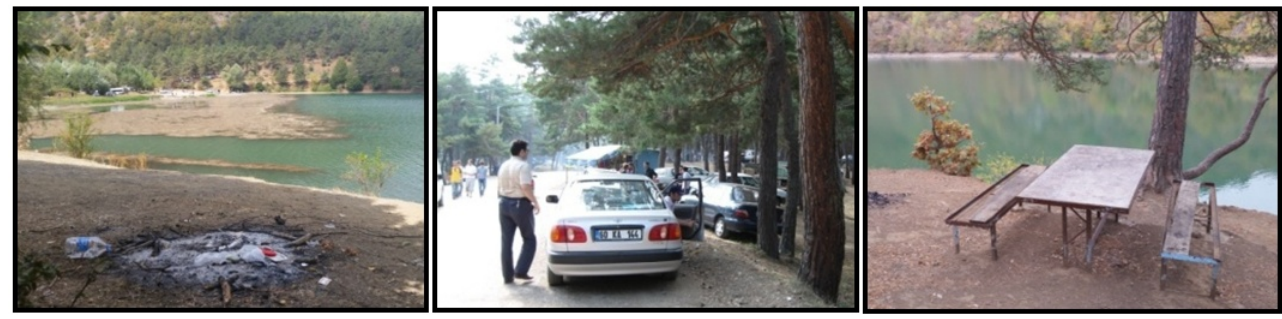

Fotoğraf 9. Görüntü kirliliği olarak algılanabilecek görünümlerden bazıları: Piknik ateşi kalıntıları, gelişigüzel park etmiş araçlar, eskimiş piknik masalart.

Söz konusu görüntü kirliliği olduğunda doğa ile uyumlu konaklama tesisleri, yer altına alınmış elektrik hatları, ahşap giydirilmiş çeşmeler, ahşap piknik masaları yörede takdiri hak eden olumlu uygulamalardır (Fotoğraf 10).

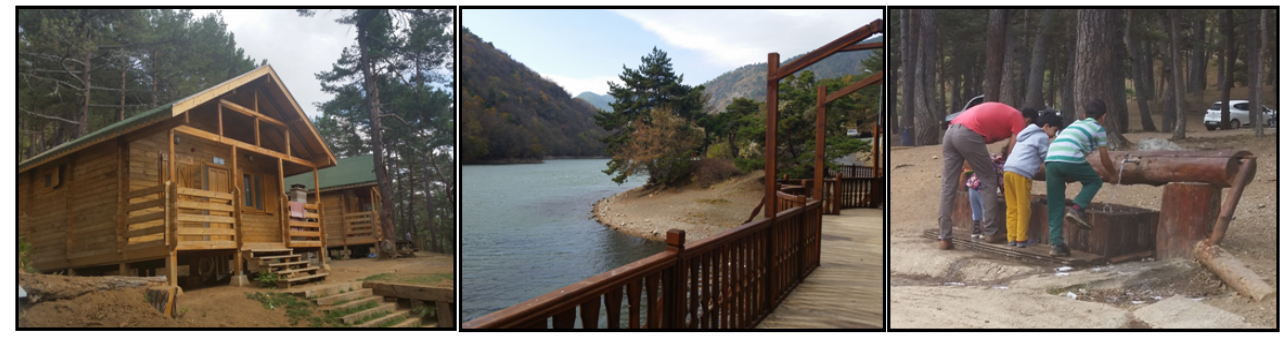

Fotoğraf 10. Son yıllarda görüntü kirliliğini önlemek adına yapılan başarılı çalışmalara örnekler: Ahşap evler, ahşap malzeme kullanılarak düzenlenen yürüyüs yolları ve çeşme.

\section{3. 6. Koku Kirliliği}

Beş duyumuzdan biri olan ve istemsiz olarak harekete geçen koku alma duyumuz, kişiye göre farklılık göstermektedir. Aynı koku farklı kişiler tarafından farklı algılanabildiği gibi, kokunun algılanış eşiği de değişiklik göstermektedir. Bu göreceli durum nedeni ile birlikte çevreye genel olarak rahatsızlık veren koku, koku kirliliği olarak tanımlanabilir. 04.09.2010 tarih ve 27692 sayılı Resmi Gazete'de 
kokuya sebep olan emisyonların kontrolüne ve azaltılmasına yönelik idari ve teknik, usul ve esasları düzenleyen yönetmelikte yayınlanmıştır. Bu yönetmelikte "insanda koku alma duyusunu harekete geçiren ve kokunun algılanmasına neden olan uçucu maddelerin yarattığı etki” koku; çöplükler, lagünler, gübre yayılan alanlar, havalandırması olmayan kompost yığınları gibi kaynaklar alansal ve yaygın koku kaynakları olarak tanımlanmıştır. Boraboy gölü ve çevresinde zamanında toplanmayan çöpler, açıkta pişirilen et kokusu ziyaretçilere rahatsızlık vermekte, koku kirliliğine neden olmaktadır. Çöplerin zamanında toplanması, piknik yapılacak alanların düzenlenmesi, sorunun çözümüne katkı sağlayacaktır.

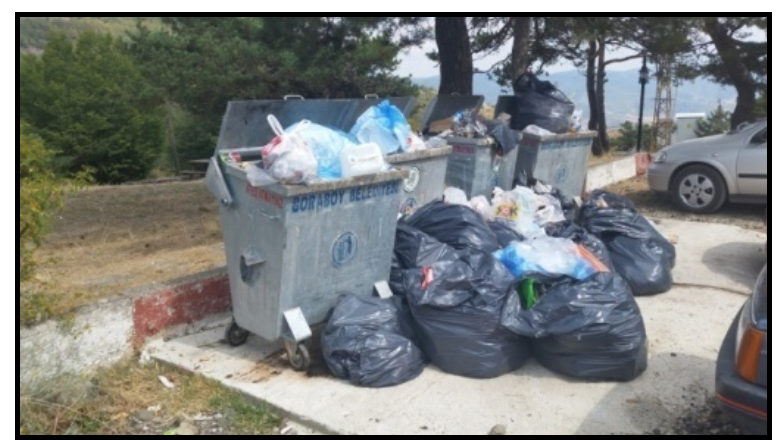

Fotoğraf 11. Çöplerin zamanında toplanmamast ve açıtkta bırakılan çöpler koku kirliliğine neden olmaktadır.

\subsection{Su Kirliliği}

İnsanlar, yaşamsal ve ekonomik gereksinimleri için suyu hidrolojik çevrimden alırlar ve kullandıktan sonra tekrar aynı döngüye iade ederler. Bu işlemler sırasında suya karışan maddeler suların fiziksel, kimyasal ve biyolojik özelliklerini değiştirerek, "su kirliliği" olarak adlandırılan olguyu ortaya çıkarır (Koloren vd., 2011:75).

Boraboy gölü, çevresindeki bitki örtüsünün rengini yansıtan, yeşile çalan berrak suya sahiptir. Çevresinde tarım ve yerleşim alanı bulunmaması su kalitesini olumlu etkilemiştir. Hal böyle olmakla birlikte ilkbahar başında kar erimesi ve yağışlara bağlı olarak göle bol su taşıyan Çatağın deresinin getirdiği rüsubat ile gölün batı kıyılarında suyun rengi değişmekte, bulanıklaşmaktadır. Şenol, Çatağın deresinin getirdiği alüvyonların göle olumsuz etkisine dikkat çekmiş, derenin göle dökülmeden önceki kısmına set çekilmesini önermiştir (Şenol, 1999:75). 2015 yılında öneriye uygun tedbir alınmış, tersib bendi yapılmıştır. Alınan bu tedbir ile hem gölün alüvyonlarla dolması hem de ilkbahar döneminde suyunun bulanıklaşması engellenmiştir (Fotoğraf 12).

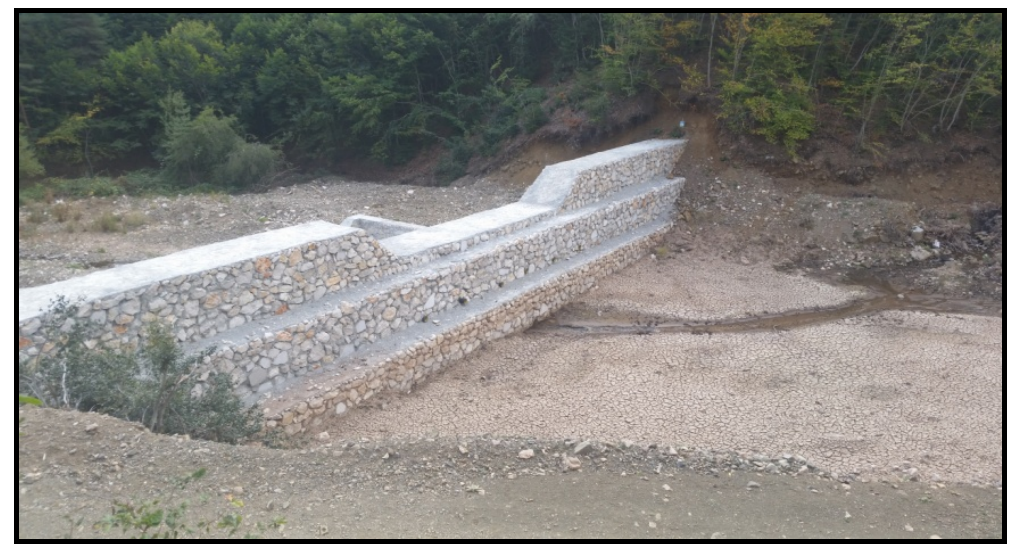

Fotoğraf 12. Çată̆ın deresinin ağız kısmına yaklaşık olarak $500 \mathrm{~m}$. kala inşa edilmiş tersib bendinden bir görünüm. 
Güney (2004:64) Meram çayında deterjan kullanımına bağlı kirlilikten bahsetmektedir. Benzer durum Boraboy gölü ve çevresinde de görülmekteydi. Buraya gelen ziyaretçiler, piknik esnasında kullandıkları araç gereçlerini göl çevresine serpiştirilmiş çeşmelerde, bulaşık deterjanı, sabun, hatta çamaşır suyu kullanarak yıkamaktadırlar. Temizlik artığı sular çeşmelerin atık su altyapısı olmadığı için yer altı suyuna karışmakta, göl havzasında yer altı suyunun ve haliyle göl suyunun kirlenmesine neden olmaktaydı. 2015 sonrasında yapılan ve atık suyun göle ulaşmasını engelleyen altyapı düzenlemesi ile sorun çözümlenmiştir. Göl çevresindeki bungalovların kanalizasyon sisteminin varlığı, göl su kalitesini korumak adına bir diğer önemli bir gelişmedir.

Yörede çöplerden sızan, çeşmelerden taşan suların yeraltına inerek göl suyuna karışma ihtimali elbette vardır (Fotoğraf 13). Ancak iyiye doğru gelişmelerin var olduğu sahada bunun, ciddi anlamda su kirliliğine yol açacağını-açtığını ifade etmek çok ta doğru olmaz. Göl içerisine atılan pet şişeler, plastik poşetler su kalitesini bozmamakla, su kirliliğinden ziyade görüntü kirliliğine neden olmaktadır. Bu da ziyaretçiler bilinçlendirilerek önlenebilir.

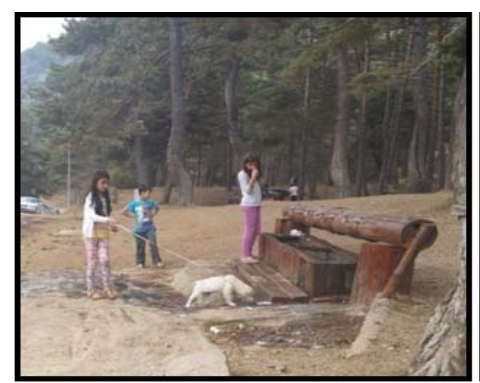

Fotoğraf 13. Su kirliliğine neden olabilecek kü̧̧ük detaylar: Çeşmeden taşan, çöplerden sızan sular, göle atılmış pet şişeler.

\subsection{Hava Kirliliği}

Havada genel olarak \%78,09 nitrojen, \%20,95 oksijen, \%0,93 argon, \%0,03 karbondioksit ve çok küçük oranlarda da diğer gazlar bulunmaktadır. Havanın normal bileşiminde bulunan-bulunmayan gazların veya partiküler maddelerin miktarları doğal ve yapay kirleticiler ile artmaktadır. Atmosferde toz, duman, gaz, koku, su buharı şeklinde bulunabilecek kirleticilerin insanlar ve diğer canlılar ile eşyaya zarar verebilecek düzeyde yükselmesi olayı hava kirliliği olarak tanımlanmaktadır (TÇSV, 1991: 27; Sungur vd., 1997: 339-340). Kum firtınaları, volkanik patlamalar, yangınlar gibi doğal olaylarda hava kirliliğine neden olmakla birlikte, daha çok motorlu taşıtlarda, sanayi tesislerinde ve evlerde fosil yakıt tüketilmesi başlıca hava kirliliği nedeni olarak kabul edilir. Göl çevresinde her ne kadar hafta sonlarında araç trafiği yoğunlaşıyor ise de bunun hali hazırda hava kirliliği şeklinde tanımlanacak düzeyde hava kalitesini bozduğunu söylemek güçtür. Göl çevresindeki hava kirliliğinin temel sebebi kontrolsüz olarak yakılan piknik ateşleridir. Bunların ters rüzgar ile birlikte, hem ateşi yakan hem de çevrede bulunan insanlara rahatsızlık verdiği gözlenmektedir (Fotoğraf 14).

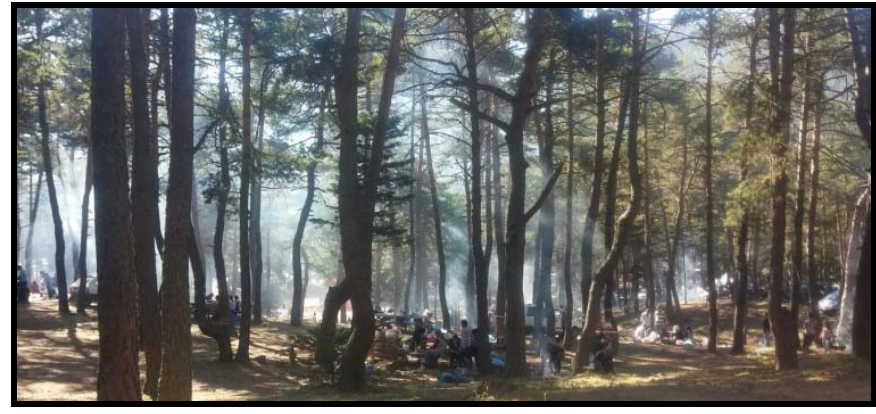

Fotoğraf 14. Ziyaretçi saylsının fazla olduğu hafta sonlarında yakılan ateşlere bağlı olarak oluşan duman hava kalitesini olumsuz etkilemektedir. 
Piknik kültürümüzün farkında olmakla birlikte, gelişigüzel ateş yakılması önlenerek, belirli noktalarda ateşler yakıllp, ürün pişirme hizmeti verilerek sorun çözümlenebilir. Araç hareketine bağl1 olarak oluşan toz özellikle yol kenarındakiler için rahatsızlık oluşturmaktadır. Piknik alanları içerisinde motorlu taşııllara izin verilmeyerek veya hız sınırı-bariyerler konularak çözüm üretilebilir.

\section{Tartışma ve Sonuc}

Göllerden sulama, içme suyu temini, balıkçılık, tuz- soda eldesi, elektrik üretimi, sportif ve rekreasyonel faaliyetler gibi amaçlarla yararlanılmaktadır. Halihazırda Boraboy gölünden sulama ve rekreasyon amaçlı faydalanma söz konusudur. Buraya daha çok yakın çevreden, piknik yapmak amacı ile, yaz döneminde özellikle hafta sonlarında günübirlikçiler gelmektedir. Sahanın rekreasyonel faaliyetlere sahne olması, göl çevresinin korunmasını sağlamıs, köyün tanınırlığına, marka değerine, ulaşım altyapısına olumlu etkide bulunmuştur. Yörede beklentilerin aksine, istihdama; diğer sektörlerin gelişmesine ve ödemeler dengesine katkısı sınırlı kalmıştır. Ekonomik faydanın arzu edilen düzeyde olmadığı bu sahada, rekreasyonel kullanımdan kaynaklanan bazı sorunlar belirmiştir.

Sahanın genelde piknik yaparak değerlendirilmesi, buna karşıllık piknik yapılabilecek sahanın sınırlarının kesin olarak belirlenmemiş olması, grupların da bu serbestliğe bağlı olarak tabiat parkı içerisinde gelişigüzel olarak yer seçiyor olmaları, sorunların temelini oluşturmaktadır. Bu bağlamda göl çevresinde piknik yapılacak birkaç bölge (kuzey bölgesi, doğu bölgesi, batı bölgesi vb. gibi) belirlenebilir. Her bir bölge piknik için gerekli unsurlar ile (piknik masası, ocak vb) ile donatılabilir. Bölge içindeki masalar numaralandırılıp harita üzerine yerleştirilebilir; girişte ziyaretçiler tercihleri doğrultusunda ilgili masaya yönlendirilebilir. Oluşturulacak basit bir yazılım ile piknik bölgelerinin doluluk oranları takip edilebilir. İhtiyaç halinde ikinci, üçüncü piknik bölgeleri kullanıma açılabilir. Böylelikle katı atık, gürültü ve koku açısından kısmi kontrol sağlanabilir.

Göl ve çevresinde güvenlik hafta sonlarında ve dini bayram tatillerinde Jandarma güçleri ile sağlanmaktadır. Toplum güvenliğine ek olarak çevrenin korunmasını sağlamak adına bir nevi zabıta hizmeti sunulabilir; çevre sorunlarına yol açanları uyarma, gerekirse kabahatler kanunu çerçevesinde cezalandırma yetkisine sahip personel istihdam edilebilir. Bu önlem özellikle piknik alanı dışında ateş yakılması, bitkilere zarar verilmesi, gürültü, çöplerin toplanmaması vb. hususlarında caydırıcı olabilir.

Göl çevresi için kanaatimce en büyük risk, değişik gerekçelerle (mangal yapmak, semaver, ısınmak vb) ateş yakılıyor olmasıdır. Piknik için belirlenen bölgeler dışında buna kesinlikle izin verilmemelidir. Ayrıca piknik bölgelerinde de olası yangına karşı müdahale sistemleri kurulmalı, bu alanlar ilgili ekipmanlarla donatılmalıdır.

Mevcut kır lokantasında, bunlara eklenecek çay bahçesi ve benzeri tesislerde yeme - içme konusunda kaliteli ve ucuz hizmet sunulmalıdır. Ziyaretçiler, piknik yapmak yerine buradaki tesisleri kullanmaya özendirilmelidir. Ziyaretçi sayısındaki artış ivmesi devam ederse, yakın gelecekte sahayı piknik yaparak kullanmak zaten mümkün olmayacaktır. $\mathrm{Bu}$ nedenle değişimin altyapısı şimdiden oluşturulmalıdır.

Sahaya gelen ziyaretçilere göl ve çevresinin önemine, neden korunması gerektiğine, başlıca sorunlarına ve bu sorunların nasıl bertaraf edileceğine dair bilgiler içeren broşürler verilmelidir. Kendilerinden istenen / beklenen davranışlar ifade edilmeli; farkındalık oluşturulmalıdır.

Göl çevresindeki en önemli sorun katı atık birikimidir. Sahada piknik yapan ziyaretçilerin atıklarını ayrıştırarak toplaması ve çöp toplama merkezlerine bırakması, daha da iyi olanı çöplerini beraberlerinde götürmeleri göl çevresindeki bu sorununun çözümüne katkı sağlayacaktır. Bu konuda ziyaretçiler bilinçlendirilmeli, telkin ve teşvik edilmelidir. Kolaycılığa kaçılarak, özellikle hafta sonlarında daha fazla temizlik personeli istihdam edilmesi, sorunun çözümü için önerilebilir. Mümkündür. Ancak sayı ne kadar artırılırsa artırılsın sorunu çözmek için yeterli olmayacaktır. Burada ziyaretçi davranışlarını olumlu yönde değiştirmek gerekecektir. Örneğin çöpünü ayrıştırarak çöp toplama merkezine getirenlere; giriş ücretinin bir kısmı getirdiği çöp miktarına göre iade edilebilir. Sarı ve Bidav Munzur Vadisi Milli Parkında yerel halkın çevreyi temizleme günleri yaptığını bildirmektedir (Sarı vd., 2017: 86). Benzer yöntem sahada uygulanarak sorunun çözümüne katkı sağlanabilir. 
Yukarıdaki önerilere ek olarak görüntü kirliliğini önlemek için otopark alanları oluşturulmall, eski donatılar yenilenmeli, çöp konteynırları doğaya uygun malzeme ile giydirilmeli, çöpler zamanında toplanmalıdır. Flora ve faunaya bilinçli olarak zarar verenler ağır şekilde cezalandırılmalıdır. Su kirliliğini önlemek adına çöp toplama alanlarının zemini çöp suyunun toprağa karışmasını engelleyecek malzemeler ile kaplanmalı; çeşmelerden taşan suların çevreye yayılması engellenmelidir. Göl çevresinde araçların toz bulutu oluşturacak hızda seyretmesi engellenmeli, hızı azaltmak adına yol üzerine bariyerler yerleştirilmelidir. Araç ve yayalar için açılan yolların kenarındaki yamaçlar taraçalandırılmalı, yamaca tutunan, yöreye uyumlu ot ve çalı türleriyle bitkilendirilmelidir.

Mevcut kullanım şeklinin ekonomik olmadığı sahada özellikle yaz döneminde, hafta sonlarında, taşıma kapasitesi aşılmakta, çevre açısından risk teşkil eden durumlar gözlenmektedir. Göl ve çevresi yılın bir döneminde kullanıldığı için, mevcut sorunlar ziyaretçi yoğunluğunun olmadığ kış sezonunda doğa tarafından tamir edilmektedir. Yıllardır turizme sahne olan saha, korunmuş olmasını birazda bu özelliğine borçludur.

Yakın gelecekte ziyaretçi sayısının artması, markalaşmaya bağlı olarak kullanım sezonunun uzaması muhtemeldir. Her iki gelişme de doğal çevre üzerindeki baskıyı artıracaktır. İvmeyi izlemek için nitelikli veri toplama yoluna gidilmelidir. Sorunların büyümesini, kökleşmesini engellemek adına ziyaretçi sayısı ve yararlanma eğilimi dikkate alınarak altyapı, tesisler, kullanım tarzı ve kullanıma açılan alanlar ile ilgili politika geliştirilmelidir. Bu kapsamda piknik yapılabilecek alanlar göl kıyısından, altyapısı oluşturulmak kaydı ile çevre alanlara (örneğin Çatağın deresinin aşağı ve orta çığırına, İkioluk mevkine vb.) doğru kaydırılabilir. Gölün kuş uçuşu 5 km kadar kuzeyinde yer alan Aşağı Yayla tabiat parkına entegre edilerek ziyaretçi yoğunluğu azaltılabilir.

\section{Kaynakça}

Akkan, E., Gürgen, G. (1993). Gaga Gölü, Ankara Üniversitesi TÜCAUM Dergisi, (2), 241-249.

Akkan, E., Doğu, A. F., Çiçek, İ., Gürgen, G., Yiğitbaşığlu, H., Somuncu, M. (1993). Uzungöl, Ankara Üniversitesi TÜCAUM Dergisi, (2), 251-262.

Akpınar, E., Akbulut G. (2007). Hafik Gölü ve Yakın Çevresinin Turizm Olanakları, Erzincan Eğitim Fakültesi Dergisi, 9 (1), 1-24.

Atalay, İ., Mortan, K. (2011). Türkiye Bölgesel Coğrafyası, İnkılap Kitabevi, İstanbul

Avşar U., Hubert-Ferrari, A., De Batist, M., Schmidt, S., Fagel, N. (2015). Sedimentary Records of Past Earthquakes in Boraboy Lake During The Last CA 600 Years (North Anatolian Fault, Turkey), ELSEVIER Palaeogeography, Palaeoclimatology, Palaeoecology, (433), 1-9.

Aylar, F., Çoban A. (2010). Amasya'da Şehirleşmeye Bağlı Olarak Ortaya Çıkan Çevre Sorunları ve Çözüm Önerileri, Sosyal Bilimler Dergisi, 12(1), 137-161.

Bekdemir, Ü., Elmacı, S., Sezer, İ. (2010). Turizmin Kıskacında Bir Doğa Koruma Alanı, Dilek Yarımadası-Büyük Menderes Deltası Milli Parkı, Turkish Studies, 5(4), 890-913.

Cansaran, A., Kaya, Ö. F., Ertekin, A. S., Ketenoğlu, O. (2010). A phytosociological study on Karaömer Mountain of North Anatolia (Amasya, Turkey), Acta Botanica Gallica, 157(1), 65-88.

Çavuş, A. (2014). Trabzon'da Doğa Turizmi Açısından Değerlendirilmesi Gereken Bir Alan: Sera Gölü, Türk Coğrafya Dergisi, (63), 43-49.

Çoban, A., Durmuş, G., Karaca, S. (2015). Üniversite Öğrencilerinin Amasya’nın Doğal ve Kültürel Turizm Değerlerine Yönelik Farkındalıkları, 08-10 Ekim 2015 III. Uluslararası Geçmişten Günümüze Merzifon Sempozyumu, Bildiriler Kitabı, 606-617.

Deniz, O. (2003). Van Kentinde Gözlenen Bazı Çevre Sorunları ve Alınması Gereken Önlemler, Doğu Coğrafya Dergisi, 8(9), 143-170.

Doğanay, H., Zaman, S. (2013). Türkiye Turizm Coğrafyası, Pegem Akademi, Ankara. 
Doğaner, S. (2001). Türkiye Turizm Coğrafyası, Çantay Kitabevi, İstanbul.

Doğu, A. F., Çiçek, İ., Gürgen, G. (1994). Borabay Gölü (Amasya), Ankara Üniversitesi TÜCAUM Dergisi, (3), 242-254.

Elmacı, S. (2010). Amasya Şehri, Çizgi Kitabevi, Konya.

Emiroğlu, F. (2009). Giresun'da Görüntü Kirliliği, Uluslararast Giresun ve Doğu Karadeniz Sosyal Bilimler Sempozyuтu, Bildiriler Kitabı, 386-395.

Evliyaoğlu, S. (1996). Türkiye Turizm Coğrafyası, Gazi Üniversitesi Eğitim Fakültesi Yayını, Ankara.

Güler, Ç. ve Çobanoğlu, Z. (1994). Gürültü, Çevre Sağllğ̆, Temel Kaynak Dizisi, No:19, Ankara.

Güney, E. (2004). Türkiye Çevre Sorunlarl, Nobel Yayın Dağıtım, Ankara.

Güremen, L. (2024). Amasya Kent Merkezi Ana Arter Yollarında Trafik Gürültüsünün Trafik Koşul ve Standartları Yönüyle Değerlendilmesi, E-Journal of New World Sciences Academy-Engineering Sciences, 9(4), 26-47.

Hoşgören, M. Y. (1994). Türkiye'nin Gölleri, Türk Coğrafya Dergisi, (29), 19-51.

İnandık, H. (1965). Türkiye’nin Gölleri, (Morfolojik ve Hidrolojik Özellikleri), İ.Ü. Coğrafya Enstitüsü Yayını, No: 44, İstanbul.

Kaya, F. (2005).Hızlı Kentleşme Sürecinde Çevre Sorunları Önemli Boyutlara Ulaşan Şehirlere İlginç Bir Örnek; Ağrı, Kastamonu Ĕ̆itim Dergisi, 13(1), 193- 206.

Koloren, Z., Taş, B., Kaya, D. (2011). Gaga Gölü (Ordu, Türkiye)'nün Mikrobiyolojik Kirlilik Seviyesinin Belirlenmesi, Karadeniz Fen Bilimleri Dergisi, 2(1), 74-85.

Köksal, A. (1994). Türkiye Turizm Coğrafyası, Gazi Büro Kitabevi, Ankara.

Lahn, E. (1948). Türkiye Göllerinin Jeolojisi ve Jeomorfolojisi Hakkında Bir Etüt, MTA Yayınları, Seri B, No:12, Ankara.

Mor, A., Çitçi, D. M. (2008). Elazığ Şehri’nin Çevre Sorunları, Doğu Coğrafya Dergisi, 13(19), 189-212.

Olalı, H. (1990). Turizm Politikası ve Planlaması, İşletme İktisadı Enstitüsü Yayını, No:122, İstanbul.

Rehber Ansiklopedisi (1984). Amasya Maddesi, Cilt:2.

Saraçoğlu, H.(1990). Bitki Örtüsü , Akarsular ve Göller, Milli Eğitim Bakanlığı Yayınevi, Öğretmen Yayınları Dizisi, No:177

Sargın, S. (2003). Isparta Şehri'nin Çevre Sorunları, Afyon Kocatepe Üniversitesi Sosyal Bilimler Dergisi, $5(2), 147-165$.

Sarı C., Bidav Y. (2017). Munzur Vadisi Milli Parkı'nda Doğal ve Kültürel Çevrenin Geliştirilmesi ve Korunması Üzerine Yöre Halkının Farkındalığı, Doğu Coğrafya Dergisi, 22(38), 63-86.

Somuncu, M., Yiğit, T. (2009). Göreme Milli Parkı ve Kapadokya Kayalık Sitleri Dünya Mirası Alanı'ndaki Turizmin Sürdürülebilirlik Perspektifinden Değerlendirilmesi, $V$. Ulusal Coğrafya Seтровуити 2008, Bildiriler Kitabı, 387-402.

Somuncu, M., Çabuk Kaya N., Akpınar, N, Kurum, E., Özelçi, T. (2012). Doğu Karadeniz Bölgesi Yaylalarında Çevresel Değişim, Ankara Üniversitesi Yayınları, No:2, Ankara.

Sungur, K., Gönençgil, B. (1997). Çeşitli İklim Elemanlarının Hava Kirliliği Üzerine Etkileri, Ankara Üniversitesi TÜCAUM Dergisi, (6), 337-345.

Şahin, C., Sipahioğlu, Ş. (2003). Doğal Afetler ve Türkiye, Gündüz Eğitim ve Yayıncılık, Ankara. 
Şahin, K. (2014). Atakum (Samsun) Şehrinde Çevresel Gürültü Kirliliği, Uluslararası Sosyal Araştırmalar Dergisi, 7(29), 722-730.

Şenol, E. (1999). Boraboy'da (Amasya-Taşova) Arazi Kullanımı, Ondokuz Mayıs Üniversitesi, Sosyal Bilimler Enstitüsü, Yayınlanmamış Yüksek Lisans Tezi.

Taş, B. (2009). Gaga Gölü Sulak Alan Ekosistemi (Fatsa, Ordu), Kırsal Çevre Yılllğğ-2009, 20-26.

TÇSV (1989). Türkiye'nin Çevre Sorunları, Türkiye Çevre Sorunları Vakfı Yayını, Önder Matbaa, Ankara.

Tuncel, M. (1975). Göllerimiz, Redhouse Yayınevi, Tabiat Bilimleri Serisi, İstanbul.

Tuncel, M., Doğaner, S. (1989). Amasya'da Turizm, Coğrafi İmkânlar. Sorunlar, Öneriler, AKDTYK Coğrafya Araştırmaları Dergisi, 1 (1), 47-68.

Türkiye Ansiklopedisi (1983). Amasya Maddesi, Cilt:2.

Yazıcı, H. Cin M. (1997). Uzungöl Turizm Merkezinde Coğrafi Gözlemler, Türk Coğrafya Dergisi, (32), 55-77.

Yıldız, K., Sipahioğlu, Ş., Yılmaz, M. (2005). Çevre Bilimi ve Eğitimi, Gündüz Eğitim ve Yayıncılık, Ankara.

Zengin, B., Öztürk, E., Salha, H. (2014). Amasya İlinin Alternatif Turizm Potansiyelinin Değerlendirilmesi, Namık Kemal University, Institute of Social Sciences Sosyal Bilimler Metinleri, 1-22

Zeybek, H. İ., Uzun, A., Yılmaz, C., Bahadır, M. (2012). Tokat İlinin Doğal Gölleri, 01-03 Kasım 2012 Tokat Sempozyumu, Bildiriler Kitabı, (2), 129-146. 